\title{
A new look at diamonds from the Koffiefontein Mine
}

\author{
Nicole A. Meyer ${ }^{1}$, Thomas Stachel ${ }^{1}$, D. Graham Pearson ${ }^{1}$, and Jeff W. Harris ${ }^{1,2}$ \\ ${ }^{1}$ University of Alberta, Edmonton, Canada, nameyer@ualberta.ca, tstachel@ualberta.ca, \\ gdpearso@ualberta.ca \\ ${ }^{2}$ University of Glasgow, Glasgow, United Kingdom,Jeff.Harris@glasgow.ac.uk
}

\section{Introduction}

The Koffiefontein kimberlite is one of the classical diamond mines on the Kaapvaal Craton and best known for being the first locality where sublithospheric inclusions in diamond were recovered (Moore et al. 1986). Koffiefontein diamonds were the first to be dated using Re-Os decay in sulphides and gave two age populations with E-type sulphides having late Archean $(\sim 2.7 \mathrm{Ga})$ and Proterozoic populations $(\sim 1.1 \mathrm{Ga})$, while a single peridotitic diamond gave an age within error of the age of kimberlite eruption (Pearson et al. 1998). Koffiefontein diamonds and their inclusions were last studied in the 1980s and, based on major advances in micro-analytical techniques, here we revisit this mine to provide improved inclusion-based geothermobarometry.

\section{Sample Set}

Our new sample set contains a variety of octahedra, dodecahedroids, macles, and irregular stones. The majority $(85 \%)$ of the crystals are colourless. Diamonds with peridotitic inclusions have a median nitrogen concentration of 67 at. ppm (range of 0 to 1580 at. ppm), eclogitic stones having a higher median at 175 at. ppm (range of 0 to 778 at. ppm). Within the new suite, 68 diamonds with peridotitic inclusions have been studied and a total of 156 olivine, Cr-rich pyrope garnet, enstatite, and diopside inclusions liberated. The peridotitic inclusion suite from Koffiefontein is dominated by a highlydepleted harzburgitic component. Most of the harzburgitic garnets $(90 \%)$ contain $\leq 3.00$ wt. $\% \mathrm{CaO}$ and strong melt-depletion is also seen in olivine data, with Mg-numbers ranging between 93 and 95 . Only $\sim 15 \%$ of the peridotitic inclusion suite is lherzolitic based on the presence of clinopyroxene inclusions or garnet inclusions that classify as G9.

\section{Geothermobarometry}

We used xenolith data from the Koffiefontein study of Cardoso (1980) to apply the more modern Cain-opx thermometer of Brey and Köhler (1990) in combination with the orthopyroxene-garnet barometer of Nickel and Green (1985, with Al in M1 calculated after Carlswell \& Gibb 1987), to estimate the paleogeotherm for the lithosphere beneath Koffiefontein. A $38 \mathrm{~mW} / \mathrm{m}^{2}$ reference geotherm (Hasterok and Chapman 2011) provides the best fit through our data (Figure 1).

For inclusions in diamond, the single-grain clinopyroxene thermometer and barometer (Nimis and Taylor 2000) was used where possible, otherwise temperature was estimated from Ca-in-opx (lherzolite, Brey and Köhler 1990) or garnet-orthopyroxene pairs (harzburgite, Harley 1984) and combined with garnet-orthopyroxene based barometry (NG85*, Nickel and Green 1985, with Al in M1 calculated after Carlswell \& Gibb 1987) to obtain P-T estimates. With one exception, the inclusion pairs were nontouching and, therefore, generally yield the conditions likely to approximate to those of diamond formation. Harzburgitic inclusions derive from close to the base of the lithosphere $\left(1160-1285{ }^{\circ} \mathrm{C}\right.$ and 60-71 kbar, five inclusion sets; and $1151{ }^{\circ} \mathrm{C}$ and $53 \mathrm{kbar}$, touching pair) whilst much rarer lherzolitic inclusions last equilibrated in the upper portion of diamond stable lithosphere $\left(985-1158{ }^{\circ} \mathrm{C}\right.$ and 48 $52 \mathrm{kbar}$, three inclusion sets; one outlier at $24 \mathrm{kbar}$, above the graphite-diamond transition). The thermometer of Harley (1984) has been shown to underestimate calculated temperature above $1000{ }^{\circ} \mathrm{C}$ (Brey and Köhler 1990), thus the harzburgitic samples (Figure 1, blue circles) may lie closer to the $38 \mathrm{~mW} / \mathrm{m}^{2}$ reference geotherm. Adding inclusion assemblages from five diamonds studied by Cardoso (1980) to our data set yields consistent results. Both harzburgitic and lherzolitic associations fall along 
the xenolith-based $38 \mathrm{~mW} / \mathrm{m}^{2}$ reference geotherm, implying that thermal conditions beneath Koffiefontein remained fairly constant over billions of years and that diamond formation occurred in a lithosphere about $220 \mathrm{~km}$ thick.

To expand our geothermobarometry data beyond rare garnet-bearing associations, we conducted highprecision trace element analyses of $\mathrm{Al}$ in olivine inclusions via EPMA. This technique allows for nondestructive, trace element analysis of olivine inclusions as small as $20 \mu \mathrm{m}$ in diameter. Using long count times (300 seconds on peak and each background) and a $200 \mathrm{nA}$ beam current, detection limits of $8 \mathrm{ppm}$ for $\mathrm{Al}$ were achieved. Based on these $\mathrm{Al}$ analyses, temperatures were calculated using the updated Al-in-olivine thermometer of Bussweiler et al. (2017) projected onto a $38 \mathrm{~mW} / \mathrm{m}^{2}$ reference geotherm. Using a set of 30 olivine inclusions, temperatures of $970-1340{ }^{\circ} \mathrm{C}$ were obtained (with one outlier at $760{ }^{\circ} \mathrm{C}$, above the graphite-diamond transition).

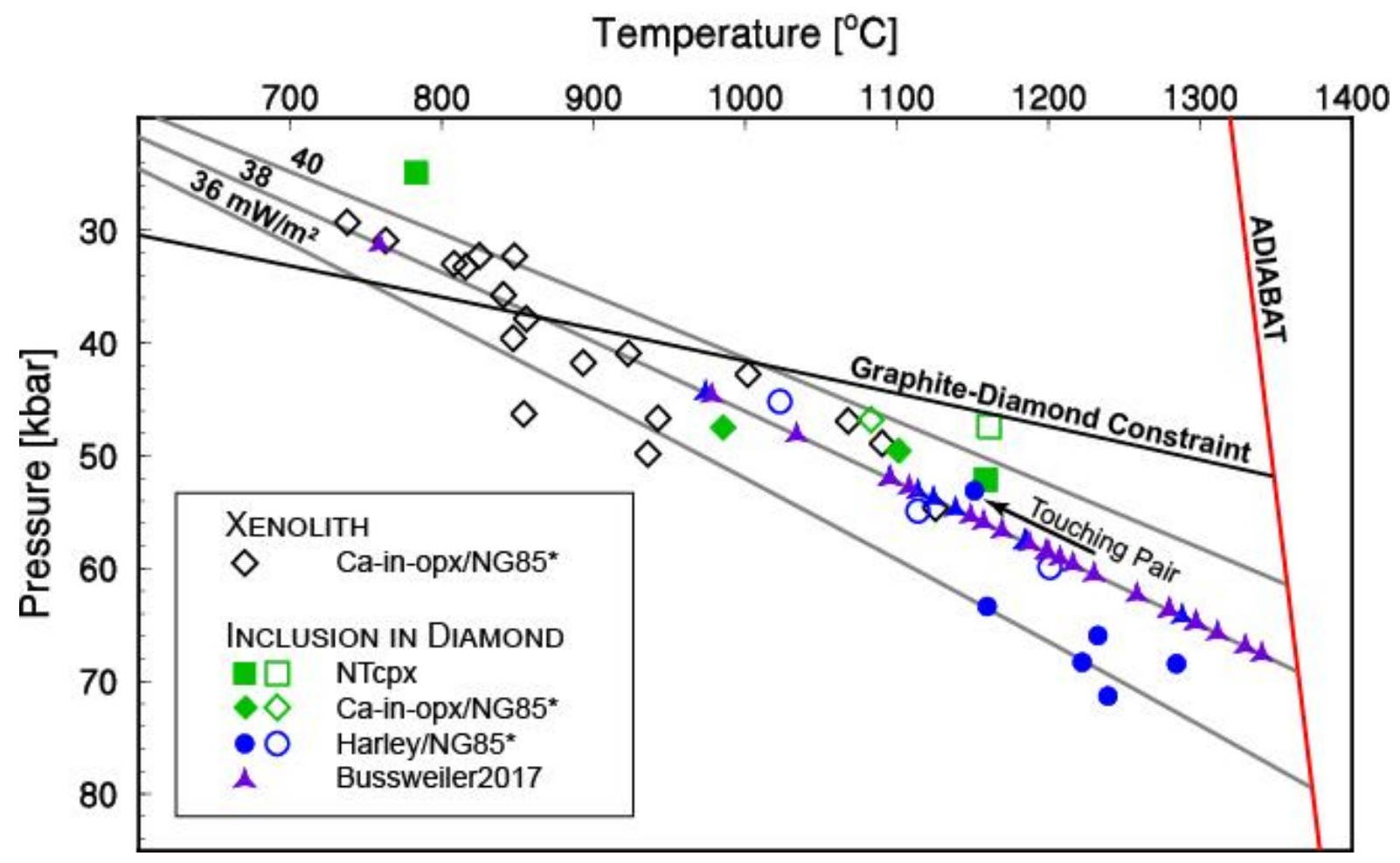

Figure 1: Pressure and temperature estimates applying modern geothermobarometers to xenolith (Cardoso 1980) and inclusion in diamond data (Cardoso 1980 and this study). Xenolith data define a $38 \mathrm{~mW} / \mathrm{m}^{2}$ reference geotherm (Hasterok and Chapman 2011). Inclusions in diamond follow the same reference geotherm but derive from much greater depth. Geothermombarometers utilised are explained in the text. Filled symbols denote data from this study and open symbols from the Cardoso (1980) study. Xenolith data is in black, with inclusion in diamond data coloured: green $=$ lherzolitic, blue $=$ harzburgitic, and purple $=$ unclassified peridotitic. Graphitediamond transition curve of Day (2012).

\section{Conclusions}

A re-investigation of existing data from Cardoso (1980) and new data on inclusions in diamond (this study) confirms the ultra-depleted nature of the Koffiefontein subcontinental lithospheric mantle, providing new insights into spatial (vertical) variations in diamond-host lithologies and into the nature of how the Koffiefontein kimberlite sampled the diamond-stability field during magma ascent. Our new geothermobarometric data indicate a cool $38 \mathrm{~mW} / \mathrm{m}^{2}$ geotherm for the Koffiefontein pipe, lower than the generally accepted average for group 1 kimberlites on the Kaapvaal craton (Grütter et al. 2006). From the expanded geothermobarometry data set, the main depth region of sampling for Koffiefontein diamonds lies between about $160-210 \mathrm{~km}$. The vertical distribution of diamond-bearing lithologies 
bears a strong resemblance to the lithological layering in the Kaapvaal cratonic lithosphere first proposed by Boyd et al. (1993), in which a zone of low-Ca, high $\mathrm{Cr}$ depleted harzburgite is concentrated in the lower section of the cratonic mantle.

\section{References}

Boyd FR, Pearson DG, Nixon PH, Mertzman SA (1993) Low-calcium garnet harzburgites from Southern Africa: their relations to craton structure and diamond crystallization. Contrib to Mineral Petrol 113:352-366.

Brey GP, Köhler T (1990) Geothermobarometry in four-phase lherzolites 2. New thermobarometers, and practical assessment of existing thermobarometers. J Petrol 31:1353-1378.

Bussweiler Y, Brey GP, Pearson DG, et al (2017) The aluminum-in-olivine thermometer for mantle peridotites - Experimental versus empirical calibration and potential applications. Lithos 272273:301-314.

Cardoso P (1980) A study of mantle inclusions in the Koffiefontein kimberlite pipe, South Africa. University of Cape Town.

Carswell DA, Gibb FGF (1987) Evaluation of mineral thermometers and barometers applicable to garnet lherzolite assemblages. Contrib to Mineral Petrol 95:499-511.

Day HW (2012) A revised diamond-graphite transition curve. Am Mineral 97:52-62.

Harley SL (1984) An experimental study of the partitioning of $\mathrm{Fe}$ and $\mathrm{Mg}$ between garnet and orthopyroxene. Contrib to Mineral Petrol 86:359-373.

Hasterok D, Chapman DS (2011) Heat production and geotherms for the continental lithosphere. Earth Planet Sci Lett 307:59-70.

Grütter HS, Latti D, Menzies A (2006) Cr-saturation arrays in concentrate garnet compositions from kimberlite and their use in mantle barometry. J Petrol 47:801-820.

Moore RO, Otter ML, Rickard, RS, Harris, JW, Gurney, JJ (1986) The occurrence of moissanite and ferro-periclase as inclusions in diamond. 4th International Kimberlite Conference, Perth, Extended Abstracts; Geological Society of Australia. 16:409-411.

Nickel KG, Green DH (1985) Empirical geothermobarometry for garnet peridotites and implications for the nature of the lithosphere, kimberlites and diamonds. Earth Planet Sci Lett 73:158-170.

Nimis P, Taylor WR (2000) Single clinopyroxene thermobarometry for garnet peridotites. Part I. Calibration and testing of a Cr-in-Cpx barometer and an enstatite-in-Cpx thermometer. Contrib to Mineral Petrol 139:541-554.

Pearson DG, Shirey SB, Harris JW, Carlson RW (1998) Sulphide inclusions in diamonds from the Koffiefontein kimberlite, S Africa: Constraints on diamond ages and mantle Re-Os systematics. Earth Planet Sci Lett 160:311-326. 